ENERGY FOR SUBSISTENCE 
Also by Margaret Haswell

ECONOMICS OF AGRICULTURE IN A SAVANNAH VILLAGE

ECONOMICS OF DEVELOPMENT IN VILLAGE INDIA

NORTHEAST THAILAND: 'Farm Gate' Surveys of

Organisational and Financial Constraints on

Development of the Marketable Surplus

THE CHANGING PATTERN OF ECONOMIC

ACTIVITY IN A GAMBIA VILLAGE

THE ECONOMICS OF SUBSISTENCE

AGRICULTURE (with Colin Clark)

THE NATURE OF POVERTY

TROPICAL FARMING ECONOMICS 


\section{ENERGY FOR SUBSISTENCE}

Margaret Haswell

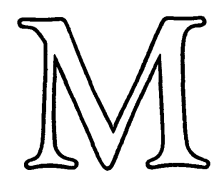


(C) Margaret Haswell 1981

Softcover reprint of the hardcover 1st edition 1981 978-0-333-28734-7 All rights reserved. No part of this publication may be reproduced or transmitted, in any form or by any means, without permission

First published 1981 by THE MACMILLAN PRESS LTD

London and Basingstoke Companies and representatives throughout the world

ISBN 978-1-349-05413-8 ISBN 978-1-349-05411-4 (eBook) DOI 10.1007/978-1-349-05411-4

Typeset in Great Britain by PREFACE LTD Salisbury, Wilts. 


\section{Contents}

List of Figures vii

List of Tables ix

Preface xi

Acknowledgements xiii

1 The Adaptive Phenomenon to Variable Amounts of Food Intake by Peoples Exposed to Extremes of Human Energy Requirements 1

Energy availability $\quad 3$

Energy utilisation $\quad 5$

Seasonality in agricultural production and the role of women

Non-agricultural activities which are independent of season

Activities performed outside the agricultural season

2 The Case History Material: a Rural People in a Tropical Environment

Traditional farming practice $\quad 23$

Time-budgets in the farming population 26

Dependency levels in the consuming population 32

3 The Emergence of Distinct Patterns of Energy Resource Utilisation $\quad 38$

Labour and social control $\quad 40$

Changes in available sources of energy 49

Food and labour implications for farm family households

4 Key Issues in Energy Resource Allocation 62

A formula for assessing the human energy supply of family farmers in subsistence economies of low-income tropical regions 
The politics of energy substitutes for food security

Appendices

Appendix I Values used in the computation of energy requirements

Appendix II Values used in the computation of energy expenditure in subsistence agriculture in Genieri village, The Gambia, West Africa 80

Appendix III Values used in the computation of energy expenditure in non-agricultural activities in Genieri village, The Gambia, West Africa

Appendix IV The energy content of some fuels, fertilisers and crop residues

References 


\section{List of Figures}

2.1 Seasonal pattern of energy expenditure on agricultural and other essential tasks: adult farmers, Genieri village

3.1 Outline of social stratification: Genieri village, 1949

3.2 Outline of social stratification: Genieri village, 1973

3.3 The change in the demographic structure of Genieri village . . . . . . . . . . . . 55

4.1 Energy value of rice yields net of fertiliser input, Laguna Province, Philippines, 1975 (farmers' fields)

4.2 The concept of 'alternative methodology' in the context of energy and time for conventional and alternative farming systems 


\section{List of Tables}

1.1 The energy value and nutrient content of some common subsistence foods

1.2 Energy output of the FAO $65 \mathrm{~kg}$ 'reference man' and $55 \mathrm{~kg}$ 'reference woman' according to level of activity

1.3 Energy for subsistence: case studies of the family in farming in England

1.4 Energy expenditure in traditional European farming dependent on hand-labour

1.5 Energy expenditure in subsistence agriculture in the tropics

1.6 Energy for subsistence in an African Savanna village economy: the contribution of male and female labour

1.7 Seasonal pattern in energy expended for subsistence in an African Savanna village economy, $1949 / 50$

1.8 Seasonal pattern of Calorie intake in an African Savanna village economy, 1948

2.1 Summary of the ratios of energy gained to energy expended in subsistence farming, Genieri village, $1949 / 50$

2.2 Age and sex distribution of farmers in Genieri village, 1949/50

2.3 Human labour utilisation in subsistence farming

2.4 Annual average 'energy balance', Genieri village, 1949/50

3.1 Mean energy expenditure at work in agriculture (including walking and resting element) in some Genieri households compared with the village average households, 1949/50 season 
3.2 Human energy supply index

3.3 Human energy required for hand-hoe agricultural production to supply the consumption needs of the household for subsistence

3.4 Human plus animal energy supply in households owning draught oxen, Genieri village, 1973/4

3.5 The 'closed economy' of Genieri village, 1949/50: aggregate hours worked in hand-hoe agriculture by age and sex

3.6 Potential cattle stocking capacity, Genieri village lands, 1973/4 


\section{Preface}

It is the current policy of governments, international agencies and aid organisations to try to find means of correcting growing imbalances between rich and poor nations, rich and poor within cities, and rich and poor between town and country. Yet, we, 'the common man', in the face of increasing shortages of the fossil fuels which support our food-systems, are reluctant to sacrifice our high standard of living for the benefit of those who continue to remain dependent on human energy for a meagre livelihood. Durnin and Passmore's Energy, Work and Leisure assesses for the prosperous industrialised nations human energy capacity by means of the rates at which we expend energy in our occupational and leisure activities. For the less-developed nations Norgan, Ferro-Luzzi and Durnin have made measurements of the human energy expenditure of subsistence farmers in Papua New Guinea. In this book these sources have been consulted in applying rates of energy expenditure to my measurements of the occupational and leisure activities of subsistence farmers in The Gambia.

Unique in my case has been the opportunity to make repeated studies of the same area, first in 1947-50, again in 1962 and 1973, and in May 1979 while in The Gambia as a delegate presenting a paper at the West Africa Rural Technology Meeting organised by the Food Production and Rural Development Division of the Commonwealth Secretariat, under the Directorship of $\mathrm{Mr}$ M. S. O. Nicholas, and the Government of The Gambia. The book should have wide applicability for research workers, teachers, policy-makers and practitioners, in the field of social and economic development. 
I should like to express my thanks to Dr N. G. Norgan, Department of Human Sciences, University of Technology, Loughborough, and to Miss Alison Paul, MRC Dunn Nutrition Unit, University of Cambridge and Medical Research Council, for their advice and encouragement in the early stages of the book's preparation. 


\section{Acknowledgements}

The author wishes to express her appreciation of the valuable research assistance which she has received from Mr P.D. Martin, Institute of Agricultural Economics, University of Oxford.

The author and publishers are grateful to William Heinemann Ltd for permission to reproduce two tables from Energy, Work and Leisure (1967) by J. V. G. A. Durnin and R. Passmore. 